stem. ${ }^{9} 10$ These actions need not always be direct ones but may be the result of a release of acetylcholine ${ }^{11}$ or other active substance or indeed secondary to alteration of the precapillary blood flow in the brain. In man the localization of nicotine in the brain may differ somewhat from that found in animals, and the resulting effects would be expected to be more complex and to be affected by mood, circumstance, or previous exposure to the drug and to be complicated by placebo response. But detailed analysis of electroencephalographic potentials by computer techniques ${ }^{12-14}$ does nevertheless indicate that smoking tends to stimulate rather than depress the central nervous system. This arousal differs little in its measurable characteristics from the stimulation which can be elicited by drugs such as lysergic acid diethylamide and amphetamine or by sensory stimulation. It is not known whether excessive or long-continued smoking can induce the depressant phase so characteristic of the action of nicotine when applied experimentally in greater than stimulant amounts. Either effect would account for the psychopharmacological result.

A large dose of acetylcholine (or a dose of nicotine) injected into the blood stream of an atropinized cat causes a rise in blood pressure, quickening of the pulse rate, and other effects consequent upon a release of catecholamine from adrenal glands. Curiously enough nicotine does not release amine directly from storage granules isolated from the adrenal, ${ }^{15}$ but it does succeed with platelets from rabbit blood. $^{16}$ It may do so from brain cells, in which case noradrenaline and dopamine would add to the central stimulant effects of nicotine ${ }^{17}$ and the rise in circulating free fatty acid and glucose due to the increased adrenal outflow would provide an energy source.

The effect of nicotine in increasing central activity in the autonomic nervous system, reinforced by its classical stimulation of autonomic ganglia, accounts for the alternation of pallor, excitement, and racing pulse (sympathetic stimulation) with nausea, slow pulse, and excessive salivation (parasympathetic stimulation) experienced by the tyro smoker. In man $^{18}$ smoking causes sinus tachycardia, an increase in cardiac output, and a widening of the pulse pressure. This is the result of sympathetic stimulation and the release of catecholamine from cardiac ${ }^{19}$ and adrenal cells. For long there has been doubt about the effect of smoking on the damaged heart, but most physicians forbid it to sufferers from angina of effort. Recently J. P. Shillingford and his colleagues have developed a method of measuring cardiac output by serial observations of dye dilution. They have reported ${ }^{20}$

'Murphree, H. B., Ann. N.Y. Acad. Sci., 1967, 142, 1.

: Armitage, A. K., Brit. Y. Pharmacol., 1965, 25, 515.

- Paton, W. D. M., and Perry, W. L. M., ’. Physiol. (Lond.), 1953, 119, 43.

S Dale, H. H., ibid., 1933, 80, 10.

- Dale, H. H., ibid., 1933, 80, 10. R. M., and Libet, B., ibid., 1961, 157, 484.

'Eccles, R. M., and Libet, B., ibid., 1961, 157, 484. $1967,142,181$.

Schmiterlöw, C. G., Hansson, E., Andersson, G., Appelgren, L. E., and Hoffmann, P.' C., ibid., 1967, 142, 2

Schaeppi, U., ibid., 1967, 102, 40.

- Hall, G. H., and Reit, E., Ұ. Physiol. (Lond.), 1966, 185, 400.

Armitage, A. K., Milton, A. S., and Morrison, C. F., ibid., 1965, 181,30 .

'Goldstein, L., and Beck, R. A., Int. Rev. Neurobiol., 1965, 8, 265.

Domino, E. F., Ann. N.Y. Acad. Sci., 1967, 142, 216.

Murphree, H. B., Pfeiffer, C. C., and Price, L. M., ibid., 1967, 142, 245 .

is Schievelbein, H., and Werle, E., ibid., 1967, 142, 72.

16 Blaschko, H., Hagen, P., and Welch, A. D., F. Physiol. (Lond.), 1955, 129,27

Milton, A. S., Brit. 9. Pharmacol., 1966, 26, 256

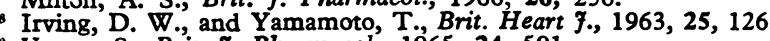

- Vanov, S., Brit. F. Pharmacol., 1965, 24, 591

- Pentecost, B., and Shillingford. J., Brit. Heart F., 1964, 26, 422. the results of an examination of the acute effects of smoking in patients. Normal persons and those with ischaemic heart disease but no evidence of infarct showed a moderate increase in output, but in patients who had had an infarct the decrease in cardiac output consequent upon inhaling cigarette smoke was very marked and in a few cases precipitated heart failure. Patients should be left in no doubt that, however it is taken, nicotine can be a dangerous drug.

\section{Revision of History}

Lay people are apt to laugh at the medical profession for following one fashion after another over the years, whether in diagnosis or in treatment. New syndromes displace old diseases and pharmacopoeias regularly undergo revision at the hands of learned committees. Doctors more usually look on all this as the displacement of ignorance by knowledge, or the reinterpretation of what was incompletely understood, rather than the more whimsical response to man's need for perpetually fresh challenges such as fashion may present in the mini- or maxi-skirt. Now, a far-ranging revision of ideas is forced on the historians. Drs. Ida Macalpine and Richard Hunter, together with Professor C. Rimington, F.R.S., ${ }^{1}$ showed in their paper in the B.M.F. last week that porphyria is the correct diagnosis for a variety of maladies thought to have afflicted many members of the royal houses of Stuart, Hanover, and Prussia. This week (p. 109) a historian, Dr. John Brooke, senior editor of the Historical Manuscripts Commission, considers some of the implications of their work

The significance of the new discoveries is evident from $\mathrm{Dr}_{\mathrm{r}}$ Brooke's comment: "They make such a difference to traditional views that it will be a long time before the historian will be able to digest them and embody them in the corpus of historical knowledge." He himself begins the process of historical digestion by discussing especially the effect on British history of the disease in George III and George IV. Their reigns spanned years of great moment to Britain-the war against the American colonies, the French Revolution, the Napoleonic wars, and the foundations of the Industrial Revolution. Though the power of the Crown in relation to Parliament is said to have declined during that period, the influence on the Crown of the gene bearing porphyria would seem nevertheless to have been so damaging as to encourage historians to look at those dramatic events with a fresh eye.

A B.M.F. booklet bringing these articles together is published this week. It contains the first article on George III's illness by Drs. Macalpine and Hunter, ${ }^{2}$ the second (in which they were joined by Professor Rimington) on porphyria in the royal houses of Stuart, Hanover, and Prussia, ${ }^{1}$ Dr. Brooke's historical essay, and an account of the porphyrias by Professor Abe Goldberg. The porphyrins, named from the Greek, are purple-red pigments, so the booklet has been given a purple cover. On its front is an engraving of George III, on the back the royal badge used by the Stuarts to symbolize the union of the crowns of England and Scotland Copies can be obtained from the British Medical fournal or from booksellers. ${ }^{3}$

1 Macalpine, I., Hunter, R., and Rimington, C., Brit. med. Y., 1968, 1

$\frac{7 .}{\text { Porphyria-A Royal Malady }}$

Porphyria-A Royal Malady (pp. 76): 12s. 6d. net, plus 1s. postage (U.S.A., \$1.50, plus 25 cents postage). Obtainable from the Publishing Manager, British Medical fournal, B.M.A. House, Tavistock Square, London W.C.1. 